\title{
Showing There is No Incompatibility Between Evolution and the Bible
}

\author{
Andrew Ter Ern Loke \\ in The 72nd Annual Meeting of the Evangelical Theological Society
}

https://doi.org/10.54739/rcx8

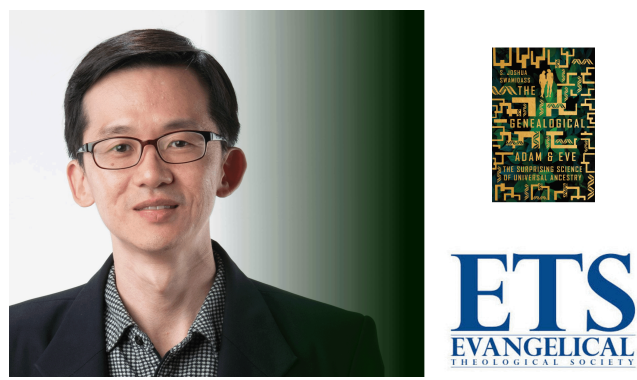

$\mathbf{T}_{\text {het }}$

here are two key issues to consider when evaluating the debate concerning the historical Adam: how to interpret the scientific data, and how to interpret the Bible. To interpret any text properly, one should follow hermeneutical principles such as considering the literary genre, literary context, meaning of words, grammatical relationship, and the background and concerns of the authors (historical, cultural, and theological). One should be careful not to interpret the Bible in accordance with our present scientific knowledge (Concordism), but in accordance with the above mentioned principles.

\section{Distinguishing between Task A and Task C}

On the other hand, we need to distinguish: (A) 'interpreting the Bible' from the other two tasks ${ }^{1}(B)$ 'showing that the Biblical account is true,' and (C) 'showing that there is no incompatibility between evolution and Bible.'

To illustrate the distinction between tasks $(A)$ and $(C)$, note the difference between (1) saying that the Bible teaches Big Bang, evolution, etc and (2) saying that the Bible does not contradict Big Bang, evolution, etc. Unlike for tasks (A) and (B), for task (C) it is perfectly legitimate to suggest a possible model which the human Biblical authors may not have thought of, as long as the possibility is not contradictory to what they expressed.

I understand Swamidass' project to belong to task (C) 'showing that there is no incompatibility between evolution and Bible.' As he writes

'Entirely consistent with the genetic and archeological evidence, it is possible that Adam was created out of dust, and Eve out of his rib, less than 10,000 years ago. Leaving the garden, their offspring would have blended with those outside it, biologically identical neighbors from the surrounding area. In a few thousand years, they would become genealogical ancestors of everyone. ${ }^{2}$

The italicized words indicate that Swamidass' is suggesting a possible model which shows how the Scripture is consistent with scientific evidence (Task C); Swamidass is not claiming that his model is an interpretation of what the Scripture affirms (Task A).

1. Andrew Loke, 'Reconciling Evolution with Biblical literalism: a proposed research program,' Theology and Science 14 (2016): 160-174.

2. Joshua Swamidass, The Genealogical Adam and Eve: The Surprising Science of Universal Ancestry (Downers Grove: Intervarsity, 2019), p. 10; italics mine.
Sadly, many critics of Swamidass' Genealogical Adam Model (GAE) have missed this simple logical distinction; they have misunderstood Swamidass' project by criticising it on the assumptions of Task A. To list some examples below:

Marcus Ross writes,

Yet there was much that troubled me as I discovered how far Swamidass's interpretations of these statements depart from historic Christian views...point to precisely zero Scriptures for explicit affirmation. ${ }^{3}$

Rob Carter and John Sanford write,

The [GAE] model is very different from the straightforward reading of Genesis 1-4...This elaborate story is only required because of his determination to force-fit deep time and evolution into the Bible...We have major concerns about his increasing willingness to rework the Bible to his own satisfaction, and his attempts impose things into the Bible that are simply not there. ${ }^{4}$

The above criticisms confuse Task A with Task C. To elaborate, the Genealogical Adam model is not intended to be an interpretation of Scriptural statements concerning Adam; that is why it does not require Scriptures for explicit affirmation because it is not intended to be a reading of Genesis 1-4. Rather, the Genealogical Adam model is intended to show how is it possible that the Scriptural statements concerning Adam do not contradict evolutionary science. By doing so it does not 'force-fit deep time and evolution into the Bible', nor rework the Bible nor 'impose things into the Bible'. Rather it proposes a scenario which is not excluded by the Bible (there is a distinction between claiming that 'the Bible says $X$ ' and 'the Bible does not exclude $X^{\prime}$, the model concerns the latter).

\section{Different Types of Genealogical Adams and Eves}

There are different types of GAE model. Some postulate Adam as the first God's-image-bearer, some do not. Swamidass defends both possibilities in his book, while I defend the first. ${ }^{5}$ My model would agree with John Stott who calls Adam 'the first man to whom may be given the Biblical designation 'made in the image of God. ${ }^{6}$ Stott writes

\footnotetext{
3. Marcus Ross 'Hedges around His garden,' Sapientia; italics mine.

4. Robert Carter and John Sanford, A 'Genealogical' Adam and Eve?; italics mine.

5. Andrew Loke. Forthcoming 2022. The Origin of Humanity and Evolution: Science and Scripture in Conversation. London: T \& T Clark.
} 
Several forms of pre-Adamic 'hominid' may have existed for thousands of years previously. These hominids began to advance culturally. They made their cave drawings and buried their dead. It is conceivable that God created Adam out of one of them. ${ }^{7}$

This model draws a distinction between 'anatomical Homo sapiens' which possessed the image of God (God's-ImageBearer = human beings) and 'anatomical Homo sapiens' which did not possess the image of God.

The fact that there are different possible GAE models implies that, even if one of the possibilities fails, this does not mean that GAE fails. In light of this, consider Madueme's objection that

the genealogical hypothesis itself is still dissonant with the biblical Adam and Eve. In that latter picture, Adam and Eve are genealogical ancestors of all human beings who have ever lived, not merely the ones alive today. ${ }^{8}$

Madueme fails to note that there are different types of GAE model presented in Swamidass's book and GAE model per se is not committed to denying that Adam and Eve are genealogical ancestors of all human beings who have ever lived.

Given Swamidass' clarification on pages 105 and 149 that he is not committed to the view which Madueme rejects, Madueme's criticism does not affect the main conclusion of the book, viz. evolutionary genetics and the existence of Adam are compatible.

\section{Responding to Grudem}

In his extensive critique of theistic evolution, Grudem has claimed that theistic evolution 'in the most common form in which it is held today' leads to twelve positions contrary to the Bible. ${ }^{9}$ Let us look at the first eight:

1. Adam and Eve were not the first human beings, and perhaps never existed.

2. Adam and Eve were born from human parents.

3. God didn't act directly or specially to create Adam out of dust.

4. God didn't act directly to create Eve from a rib taken from Adam.

5. Adam and Eve were never sinless human beings.

6. Adam and Eve did not commit the first human sins

7. Human death did not begin as a result of Adam's sin.

6. John Stott, Understanding the Bible Expanded edition (London: Scripture Union, 1984), pp. 48-49.

7. Ibid.

8. Hans Madueme. Evolution and Historical Adam? A Provocative But Unconvincing Attempt, The Gospel Coalition.

9. Wayne Grudem, 'Theistic Evolution undermines twelve creation events and several crucial Christian doctrines,' in Theistic Evolution: A Scientific, Philosophical, and Theological Critique edited by J.P. Moreland et al (Wheaton, IL: Crossway, 2017).
8. Not all human beings have descended from Adam and Eve.

In light of the previous sections of this paper, it is evident that a theistic evolutionist who holds to the type of GAE model which postulates Adam as the first God's-image-bearer can in fact deny all of the above positions! ${ }^{10}$ But Grudem has other concerns; let's take a look at positions 9 and 10:

9. God did not directly act in the natural world to create different kinds of fish, birds, and land animals. This also means that,

10. There was no special activity of God from which he "rested."

In response, it should be noted that, in contrast with atheistic/deistic evolution, Theistic Evolution/Evolutionary Creationism affirms macroevolution and affirms that there is a God who created the universe and also intervened in the history of the universe. Different interventions have been affirmed by different proponents, for example

- God intervenes in the process of macroevolution.

- God intervenes in the creation of the first common ancestor.

- God intervenes in the creation of the first human.

- God intervenes in the acts of Special Revelation (e.g. resurrecting Jesus).

Consider, for example, the view of Harvard astronomer Owen Gingerich who affirms that God intervenes in the process of macroevolution. Gingerich writes

Most mutations are disasters, but perhaps some inspired few are not. Can mutations be inspired? Here is the ideological watershed, the division between atheistic evolution and theistic evolution, and frankly it lies beyond science to prove the matter one way or the other. Science will not collapse if some practitioners are convinced that occasionally there has been creative input in the long chain of being. ${ }^{11}$

Therefore, a theistic evolutionist can also deny positions 9 and 10 by affirming that God directly acted in the natural world to create different kinds of fish, birds, and land animals through His 'creative input' (Gingerich) in the process of evolution, and that God 'rested' from this special activity on Day 7.

Finally, let's consider positions 11 and 12:

11. God never created an originally very good natural world-a safe environment, free of thorns, thistles, and other harmful things.

12. After Adam and Eve sinned, God did not place any curse on the world that changed the workings of the natural world, making it more hostile to mankind.

In reply, consider Augustine's view that 'Thorns and thistles shall it bring forth to you' (Genesis 3:18) does not imply the conclusion that it was only then that these plants came forth from the earth.

10. See also Loke, 'Reconciling Evolution with Biblical literalism: a proposed research program.'

11. Owen Gingerich, God's Universe (Cambridge, Mass.: Harvard University Press 2006), p. 69 
For it could be that, in view of the many advantages found in different kinds of seeds, these plants had a place on earth without afflicting man in any way. But since they were growing in the fields in which man was now laboring in punishment for his sin, it is reasonable to suppose that they became one of the means of punishing him. For they might have grown elsewhere, for the nourishment of birds and beasts, or even for the use of man. (Augustine, The Literal Meaning of Genesis, 1:3:18).

With a GAE model, we can affirm that Adam was placed in a divinely protected environment (Eden) which occupied a limited geographical area on earth, and after he sinned the ground on which he lived was cursed in the sense that it no longer had that divine protection.

Concerning the exegesis of Romans 8 mentioned by Grudem, the portrayal of creation groaning in labor pains in Romans 8:22 may well be connected with Jeremiah 4:23-31, which portrays the plight of the earth which resulted from the moral and spiritual failure of God's people in the Old Testament (the Israelites): ${ }^{12}$

I looked on the earth, and behold, it was without form and void; and to the heavens, and they had no light...For I heard a cry as of a woman in labor, anguish as of one giving birth to her first child, the cry of the daughter of Zion gasping for breath, stretching out her

12. Clarke Morledge, The Groaning of Creation in Romans 8:19-23 2015

\section{References}

Andrew Loke, 'Reconciling Evolution with Biblical literalism: a proposed research program,' Theology and Science 14 (2016): 160-174. https://doi.org/10.1080/14746700.2016.1156328

S. Joshua Swamidass, The Genealogical Adam and Eve: The Surprising Science of Universal Ancestry (Downers Grove: Intervarsity, 2019

Marcus Ross 'Hedges around His garden,' Sapientia.

Robert Carter and John Sanford, A 'Genealogical' Adam and Eve?.

Andrew Loke. Forthcoming 2022. The Origin of Humanity and Evolution: Science and Scripture in Conversation. London: T \& T Clark. hands, 'Woe is me! I am fainting before murderers (Jeremiah 4:23-31 ESV).

The Hebrew words translated as 'without form and void' (i.e. tōhû wābōhû) in Jeremiah 4:23 are the same words used in Genesis 1:2, which describes the state before the cursing of the ground in Genesis 3:17 (ibid).

Thus what the Biblical writers are trying to convey may well be this: God subjected creation to futility and bondage to decay (this may be related to Angelic Fall rather than human Fall), to be subdued by God's people who sadly failed to accomplish their mission due to their moral and spiritual failures. This brought death to the human race (Romans 5:12) and resulted in creation being left in a state of groaning, which will finally be liberated at the final redemption of God's people.

\section{Conclusion}

In conclusion, many criticisms of GAE model are based on misunderstandings, such as confusing the task of $(A)$ 'interpreting the Bible' with (C) 'showing that there is no incompatibility between evolution and Bible,' and failing to note that there are different types of GAE model. A theistic evolutionist can use the GAE model to answer the twelve objections to theistic evolution raised by Grudem, and this is a highly significant result in theological anthropology.

John Stott, Understanding the Bible Expanded edition (London: Scripture Union, 1984.

Hans Madueme. Evolution and Historical Adam? A Provocative But Unconvincing Attempt, The Gospel Coalition.

Owen Gingerich, God's Universe (Cambridge, Mass.: Harvard University Press 2006)

Augustine, The Literal Meaning of Genesis.

Clarke Morledge, The Groaning of Creation in Romans 8:19-23 2015. 